\title{
Effects of Residue Management and Cropping Systems on Wheat Yield Stability in a Semiarid Mediterranean Clay Soil
}

\author{
Rachid Mrabet \\ Institut National de la Recherche AgroNomique (INRA), Regional Agricultural Research Centre of Tangier, Tangier, Morocco. \\ Email: rachidmrabet@gmail.com
}

Received February 11 ${ }^{\text {th }}, 2011$; revised April 4 ${ }^{\text {th }}, 2011$; accepted April $10^{\text {th }}, 2011$.

\begin{abstract}
Agriculture is the single biggest user of land and water in Morocco; however its performances are still low due to high rainfall variation and rates of soil productivity depletion. Increasing concerns about soil and environment quality degradation have raised the need to review existing tillage management systems and develop new systems for seed-bed preparation. Consequently, No-tillage is found a promising practice of soil management to improve simultaneously soil quality and wheat production in semiarid Morocco. However, residue management under No-tillage was not yet studied in conjunction with wheat rotation. Therefore, a field study was conducted in the semiarid Chaouia Plain of Morocco during the period from 1994 to 2003, in order to evaluate the impacts of different tillage practices (conventional tillage $(C T)$, No-tillage (NT)); No-tillage wheat residue management scenarios (total $N T_{r}$, partial $N T_{p}$ and No-removal of residues $N T_{m}$ ) and crop rotations (continuous wheat $(C W)$, Wheat-Fallow (WF), Wheat-Maize-Fallow (WMF), Wheat-Lentil-Fallow (WLF) and Wheat-Barley-Fallow (WBF)) on wheat production. Over-years, conventional tillage system permitted lower yield of wheat while NT maintenance of crop residue at the surface is needed to increase it. Basically, $N T_{p}$ could be adopted in mixed crop-livestock systems of semiarid areas for the purpose of guarantying grain and feed. Wheat yields were the lowest under continuous wheat for all years. Wheat-fallow rotation is an important option in dry years or areas, while wheat-fallow-lentil or barley rotations are recommended in better environments. Stability analysis indicated that yields in the No-tillage system were less influenced by adverse growing conditions than conventional tillage system, particularly under low rainfall. These results indicate that improved soil quality under No-tillage enhanced wheat yield stability by reducing the impact of adverse growing conditions.
\end{abstract}

Keywords: No-Tillage, Residue Management, Wheat, Cropping System, Stability Analysis, Morocco

\section{Introduction}

In the Mediterranean basin, water is the most limiting factor. In fact, agriculture triggers drought, soil degradation and erosion processes [1]. Crop mis-intensification, conventional tillage and over-grazing characterize agricultural systems. These typical agricultural practices assure some production and income in wet years, but low average yields and low moisture utilization efficiency in dry years. Moreover, current practices suffer from high year-to-year variations in income and extreme fluctuations in production with very little biomass and nutrient returned to the soil and little protection provided from endemic water and wind erosion. The population growth in Morocco resulted in increased reliance upon continuous cropping rather than conservation cropping systems
[2]. In fact, continuous wheat occupies $30 \%$ of arable lands, even though it is a permanently stressed environment [3].

Soil degradation is both a cause and consequence of the poor economical development and social environment in the country. Consequently, farming systems need to be adjusted to face a range of challenges, especially water shortage and scarcity and low fertility soils [4]. Morocco's agriculture should experience a shift based upon conservation and intensification. In the other side, world-wide and in the Mediterranean basin, No-tillage systems are among the top technologies to mitigate drought, reduce tillage costs, conserve soil and water, increase soil organic carbon pools, boost crop productivity and reduce net $\mathrm{CO}_{2}$ emissions, which contribute to global warming attenuation [5-7]. Hence, under these 
environmental and weather conditions, to increase the yield stability in cereal crops represents an important objective for agricultural progress.

Winter cereals have shown better adaptability to Notillage techniques than other crops [8-13]. In Morocco, early No-tillage research, which started in 1983, showed superiority of No-tillage grain production compared to conventional tillage production $[14,15]$. It was also found that No-till soil conditions favour more vigorous and healthier plants that are resilient to various types of stress (either biotic or edaphic) [16]. A new soil ecosystem is created with adoption of No-tillage systems characterized mainly by higher sequestration of carbon, better aggregation and improved availability of essential elements to crops (nitrogen, phosphorus and potassium) $[17,18]$.

Crop residues left on the surface under zero-tillage protect the soil surface from water and wind erosion and from the sun's radiation, propitiating soil biological activity and bio-diversity, while improving nutrient efficiency, water economy and soil structure. Consequently, the best practice is to leave a fraction of crop residues in the field, where they serve as soil cover and organic amendment. For achieving sustainable mixed agricultural systems, crop residue should be managed to simultaneously increase water availability and satisfy soil quality and productivity requirement as well as livestock fodder.

Global climate change scenarios predict that variation in precipitation patterns will increase in Morocco resulting in frequent extreme events (drought and flood) [19]. For the transition and then the shifting from intensive to No-tillage systems, enhanced yield stability is of paramount importance for sustainable agriculture [20,21]. In addition, according to [22], a Non-decreasing trend in yield is necessary to call a system sustainable. Hence, the main objectives of this study are 1) to reduce dependence on tillage, while increasing the use of precipitation during the wheat growth through residue management, 2) to propose appropriate cropping system for semiarid farmers of Morocco and 3) to check on yield stability due to crop management strategies vis-à-vis changing climate and environmental contexts.

\section{Materials and Methods}

\subsection{Site Description}

A long-term field experiment was established at Sidi El Aydi experimental station to compare the sustainability of a range of rotation, tillage and stubble management systems on a clay soil. This research site is located at the Institut National de la Recherche Agronomique (INRA) $\left(33^{\circ} 00^{\prime} \mathrm{N}, 09^{\circ} 22^{\prime} \mathrm{W}\right.$, elevation $230 \mathrm{~m}$ a.s.l.) situated 45 km South of Casablanca, Morocco. The region, named
Chaouia, is the major cereal production in the country.

This experiment was set up from 1994 to 2003, with the same treatments applied to the same plot year after year. Precipitation was measured with a standard rain gauge adjacent to the plots. The major characteristics of the soil are given in Table 1. The soil of the experimental area is classified as Vertic Calcixeroll with little or No slope, representing the major soil in the region. It is characterized by cracking-swelling properties [16].

Long-term wheat growing season rainfall (1967-2003) at Sidi El Aydi averages $308.9 \mathrm{~mm}$, ranging from 113.5 $\mathrm{mm}$ to $740 \mathrm{~mm}$, with about 53.5\% received between November and January (Table 2). Maximum temperatures can reach up to $34.4^{\circ} \mathrm{C}$ in July, while minimum temperatures can drop to $6^{\circ} \mathrm{C}$ in January. Summers are hot and dry, whereas winters are cold and moist (Table 3).

\subsection{Experimental Design and Treatments}

Prior to the experiment commencement in 1994, the site had a long history of continuous wheat cropping using conventional tillage. The experimental design was a two-factorial split-plot design with three replicates. Large plots were $6 \mathrm{~m}$ wide and $20 \mathrm{~m}$ long, while sub-plots are 3 $\mathrm{m}$ wide and $20 \mathrm{~m}$ long. Large plots corresponded to rota-

Table 1. Selected soil properties of the test site at the start of the experiment for 0 to $200 \mathrm{~mm}$ depth.

\begin{tabular}{ll}
\hline Property & Value \\
\hline Sand (\%) & 21 \\
Silt (\%) & 28 \\
Clay (\%) & 51 \\
Quartz (\%) & 66.8 \\
Montmorillonite (\%) & 29.9 \\
Albite (\%) & 3.3 \\
Calcium carbonate (\%) & 15 \\
Organic carbon (\%) & 1.40 \\
pH (1:2 soil:water) & 8.2 \\
Cation Exchange Capacity $\left(\mathrm{meq} \cdot \mathrm{l}^{-1}\right)$ & 50 \\
Exchangeable bases $\left(\mathrm{mg} \cdot \mathrm{kg}^{-1}\right)$ & \\
$\bullet \mathrm{K}$ & 319 \\
$\bullet \mathrm{Na}$ & 154 \\
$\bullet$ Ca & 8040 \\
$\bullet \mathrm{Mg}$ & 351 \\
Dry bulk density $\left(\mathrm{g} \cdot \mathrm{cm}^{-3}\right)$ & 1.28 \\
Soil moisture at $1 / 3 \mathrm{bar}\left(\mathrm{cm}^{3} \cdot \mathrm{cm}^{-3}\right)$ & 0.39 \\
Soil moisture at $15 \mathrm{bars}\left(\mathrm{cm}^{3} \cdot \mathrm{cm}^{-3}\right)$ & 0.20 \\
\hline
\end{tabular}


Table 2. Wheat growing season monthly rainfall for the study period (1994-2003) and for the long-term records (1967-2003).

\begin{tabular}{|c|c|c|c|c|c|c|c|c|c|c|c|}
\hline \multirow[b]{2}{*}{ Month } & \multicolumn{11}{|c|}{ Rainfall (mm) } \\
\hline & $\begin{array}{l}1994- \\
1995\end{array}$ & $\begin{array}{c}1995- \\
1996\end{array}$ & $\begin{array}{l}1996- \\
1997\end{array}$ & $\begin{array}{c}1997- \\
1998\end{array}$ & $\begin{array}{c}1998- \\
1999\end{array}$ & $1999-2000$ & $\begin{array}{l}2000- \\
2001\end{array}$ & $\begin{array}{l}2001- \\
2002\end{array}$ & $\begin{array}{l}2002- \\
2003\end{array}$ & Average & $\begin{array}{l}\text { Long-term } \\
\text { Average }^{\mathrm{a}}\end{array}$ \\
\hline November & 33 & 43.2 & 37 & 76.9 & 0 & 36 & 13.4 & 16.3 & 189.1 & 49.4 & 49.2 \\
\hline December & 0 & 74.2 & 231.8 & 103.5 & 68.1 & 33.3 & 98.8 & 146.9 & 29.1 & 87.3 & 60.4 \\
\hline January & 0.5 & 176 & 74.1 & 36.2 & 54.2 & 31 & 66.5 & 0 & 25.8 & 51.6 & 55.7 \\
\hline February & 32 & 28.7 & 1 & 44.7 & 23.1 & 0 & 0 & 4 & 22.2 & 17.3 & 49.6 \\
\hline March & 06 & 74.7 & 17.8 & 8.5 & 26 & 0 & 0 & 60.8 & 29.3 & 24.8 & 42.8 \\
\hline April & 39.5 & 1.7 & 58.8 & 8.1 & 0 & 41.6 & 0 & 52.4 & 20.9 & 24.8 & 37.6 \\
\hline May & 2.5 & 41.5 & 0 & 0 & 21 & 10.5 & 10 & 4.7 & 2.5 & 10.3 & 13.4 \\
\hline Total & 113.5 & 440 & 420.5 & 277.9 & 192.4 & 152.4 & 188.7 & 285.1 & 318.9 & 265.5 & 308.7 \\
\hline $\begin{array}{l}\text { Deviation of } \\
\text { total }^{\text {b }}\end{array}$ & -195.4 & 131.1 & 111.6 & -31.0 & -116.5 & -156.5 & -120.2 & -23.8 & 10.0 & -43.4 & \\
\hline $\begin{array}{l}\text { Vegetative } \\
\text { Phase }^{\mathrm{c}}\end{array}$ & 57.70 & 73.20 & 81.80 & 94.00 & 75.60 & 65.81 & 94.70 & 58.65 & 83.47 & 77.44 & 69.61 \\
\hline $\begin{array}{l}\text { Reproductive } \\
\text { - Maturity } \\
\text { Phase }^{\mathrm{d}}\end{array}$ & 42.30 & 26.80 & 18.20 & 6.00 & 24.40 & 34.19 & 5.30 & 41.35 & 16.53 & 22.56 & 30.39 \\
\hline
\end{tabular}

${ }^{\mathrm{a}}$ Long-term rainfall average (1967-2003); ${ }^{\mathrm{b}}$ Deviation of growing season total from long-term total (1967-2003); ${ }^{\mathrm{C}}$ Phase assumed from November to February (\% of growing season rainfall); ${ }^{\mathrm{d}}$ Phase assumed from March to May (\% of growing season rainfall).

Table 3. Long-term mean monthly minimum/maximum temperature and pan evaporation at the experimental site [17].

\begin{tabular}{lccc}
\hline \multirow{2}{*}{ Month } & \multicolumn{2}{c}{ Temperature ${ }^{\mathrm{a}}\left({ }^{\circ} \mathrm{C}\right)$} & $\begin{array}{c}\text { Class A Pan } \\
\text { Evaporation }{ }^{\mathrm{b}}(\mathrm{mm})\end{array}$ \\
\cline { 2 - 3 } January & 6.0 & 20.0 & 78 \\
February & 7.2 & 21.3 & 89 \\
March & 8.7 & 23.7 & 112 \\
April & 10.3 & 25.3 & 138 \\
May & 12.7 & 27.4 & 206 \\
June & 15.9 & 30.6 & 219 \\
July & 18.0 & 34.4 & 308 \\
August & 20.2 & 31.8 & 294 \\
September & 18.2 & 31.6 & 225 \\
October & 12.8 & 28.7 & 157 \\
November & 10.1 & 24.1 & 100 \\
December & 8.4 & 21.4 & 72 \\
Average & 12.4 & 26.7 & 1998 \\
Total & & & \\
\hline
\end{tabular}

adata of 1967 to 1998 . 'data of 1985 to 1996. tion and sub-plot to tillage-residue management system. Five rotations were studied (Table 4). All phases (rotation-year) of each rotation were present each year and each treatment was cycled on its assigned plot. Two tillage systems were established: conventional tillage with off-set disk (CT) and Zero-tillage system. The most common tillage practice is to prepare a seedbed by disk harrowing after stubble grazing along the summer. Nearly all stubble and crop residues are normally removed from the field (via grazing or balling). The use of disk harrowing helped to break clods and make a proper seedbed, which is believed to capture and store autumn precipitation in soils. The number of off-set disk operations to prepare seedbeds differed among years and crops. Tillage depth ranged from 100 to $150 \mathrm{~mm}$, depending upon the conditions of the soil at time of tillage. These practices have been shown to exacerbate degradation of soils, promote erosion and reduce production potential. In this study, stubble and plant residues were totally incorporated with tillage tools (under CT).

The experimental design combined tillage and stubble treatments to allow their separate effects on grain yield to be assessed (Table 4). Here, "tillage-residue management" denotes these combinations as shown in Table 4. Zerotillage system (NT) received No-tillage and the only soil disturbance was for seeding and fertiliser banding. 
Table 4. Description of cropping sequences and tillageresidue management systems used in the experiment and their abbreviations.

\begin{tabular}{ll}
\hline $\begin{array}{l}\text { Cropping system: } \\
\text { Abbreviation }\end{array}$ & Sequence's description \\
\hline $\mathrm{CW}$ & Continuous Wheat \\
WF & Wheat-Fallow \\
WBF & Wheat-Barley-Fallow \\
WMF & Wheat-Maize-Fallow \\
WLF & Wheat-Lentil-Fallow \\
\hline Tillage and Residue Man- & System's description \\
viation & $\begin{array}{l}\text { Total or full removal of flat residues } \\
\text { in no-tillage wheat phase for fodder } \\
\text { use (no-mulch cover). }\end{array}$ \\
\hline $\mathrm{NT}_{\mathrm{r}}$ & $\begin{array}{l}\text { Partial removal of flat residues in } \\
\text { no-tillage wheat phase (50 - 60 per- } \\
\text { cent mulch cover) with uniform cover } \\
\text { of the soil. }\end{array}$ \\
$\mathrm{NT}_{\mathrm{p}}$ & $\begin{array}{l}\text { Total maintenance of flat residues in } \\
\text { no-tillage wheat phase (full mulch } \\
\text { cover) with a layer of several centi- } \\
\text { meters in thickness. } \\
\text { Conventional tillage with off-set disk } \\
\text { harrows-biomass incorporated. }\end{array}$ \\
\hline &
\end{tabular}

Note: After wheat harvest, stubble was approximately $10-15 \mathrm{~cm}$ tall and was not removed from no-tillage treatments. Under no-tillage systems, stubble and crop residue from other crops were maintained at the surface, while under conventional tillage, this biomass was incorporated in the soil with disking.

Smallholders in mixed crop-livestock systems constitute a very large fraction of farming enterprises in Morocco. In those systems, crop residues are a strategic production component. This study aims at better understanding the tradeoffs in crop residue uses in cereal based systems. The major trade-off in most systems is the short term benefits of using crop residues to feed livestock versus leaving the crop residues in the field to improve water management and availability as well as soil productivity (nutrient balance, erosion control and soil health). Consequently, in order to help devise these farmers for possibilities of integrating grain and livestock production, three No-tillage wheat residue management scenarios were investigated (total $\mathrm{NT}_{\mathrm{r}}$, partial $\mathrm{NT}_{\mathrm{p}}$ and No-removal of residues $\mathrm{NT}_{\mathrm{m}}$ ). Because of the high opportunity cost of crop stubbles and straw in traditional mixed farming systems, there may be a temptation to adopt a No-tillage system $\left(\mathrm{NT}_{\mathrm{m}}\right)$ while persisting with removal of stubble for other uses (livestock, fuel and commodity). In the other two options, NT has to be adopted as a system, combining both direct seeding and either full or selective retention of crop residues at the soil surface. The $\mathrm{NT}_{\mathrm{p}}$ help to explore sharing and optimizing crop residues between No-tillage and traditional or energy uses [23].

\subsection{Crop Management, Fertilization and Pest Control}

In this study, we tested the performance of alternative rotations to the typical wheat monoculture in a rainfed Mediterranean semiarid area of south-western Morocco under No-tillage (NT) and conventional tillage systems. Hence, four other rotations were established and maintained over 9-yr period (1994-1995 to 2002-2003): a wheat-barley-fallow rotation (W-B-F), a wheat-MaizeFallow rotation (W-M-F) and Wheat-Lentil-Fallow (WLF) rotation (Table 4).

In 1995-1995 to 1996-1997, a No-till drill equipped with coulters, double-disk openers and single press wheels with $0.25 \mathrm{~m}$ row spacing (TYE, The TYE Company, Lockney, USA) was used to plant wheat, barley and lentil in all plots. In 1997-1998 to 2002-2003, wheat was planted in a $0.25 \mathrm{~m}$ spacing using a research prototype hoe-type No-till drill built at INRA-Dryland Research Center, Settat, Morocco. This newly developed drill permitted $\mathrm{N}$ and $\mathrm{P}$ fertiliser placement beneath the seeds. Winter wheat (Triticum aestivum L. cv Achtar or Tilila) and barley (Hordeum vulgare L. cv ACSAD 60, Laanacer or Aglou) were sown $30-50 \mathrm{~mm}$ deep at a seed rate of $120 \mathrm{~kg} \cdot \mathrm{ha}^{-1}$.

Like many leguminous crops, lentil (Lens culinaris L. cv Bakria) plays a key role in crop rotation due to their ability to fix nitrogen. It was seeded using the No-till wheat drills at a rate of $60 \mathrm{~kg} \cdot \mathrm{ha}^{-1}$ at spacing of $0.50 \mathrm{~m}$.

Corn (Zea mays L.) is cultivated throughout the Chaouia region in rotation with wheat. Corn varieties (Mabchoura and Doukkalia) were planted either using a commercial 4-row No-till planter or manually in rows spaced $0.60 \mathrm{~m}$ and thinned to 60 - 65 thousands plants per hectare. Time of seeding for wheat, barley and lentil crops varied from 20 November to 5 December. Corn planting date ranged from mid-February to mid-March depending on the soil moisture. All field-crop varieties are adapted to the environment of Sidi El Aydi.

Soil analysis permitted the following fertilizer recommendations: ammonium nitrate $(33.5 \% \mathrm{~N})$, at a rate of 75 $\mathrm{kg} \cdot \mathrm{ha}^{-1}$, and triple super phosphate $\left(45 \% \mathrm{P}_{2} \mathrm{O}_{5}\right)$, at a rate of $100 \mathrm{~kg} \cdot \mathrm{ha}^{-1}$, were placed in the seed row as starter fertilizers for wheat, lentil and barley. Additional urea fertilizer $(46 \% \mathrm{~N})$ was broadcast at the mid-tillering stage of wheat $\left(50 \mathrm{~kg} \cdot \mathrm{ha}^{-1}\right)$. For Corn, ammonium nitrate (100 kg of material per hectare) and triple super phosphate (50 kg of material per hectare) were applied at 
planting. Soil tests at Sidi El Aydi indicate high K and therefore $\mathrm{K}$ fertilizer was not applied. These application rates ensured that nutrients $(\mathrm{N}, \mathrm{P})$ were not limiting production and crops did not exhibit any deficiency symptoms. No irrigation or farm manure was used in this experiment.

Pre-plant herbicides were used for weed control in all treatments. No-till treatments were sprayed with glyphosate at $2-3 \mathrm{~L} \cdot \mathrm{ha}^{-1}$ to control any standing vegetation during the week before crop planting. Before seeding, all wheat, barley and fallow plots were sprayed with chlorosulfuron herbicide (10 to $20 \mathrm{~g} \cdot \mathrm{ha}^{-1}$ ). Corn and lentil were sprayed at seeding with simazine at rate of 1.5 and $1 \mathrm{~L} \cdot \mathrm{ha}^{-1}$, respectively.

\subsection{Measurements}

Climatic data were collected between 1994 and 2003 at the Sidi El Aydi Experimental Station, less than $1 \mathrm{~km}$ from the experimental site. Precipitation data were collected daily throughout the wheat growing season and summarized as monthly means. Historical climatic data were obtained from the same weather station.

At harvest, wheat grain was harvested at $10-15 \mathrm{~cm}$ above ground from the plot area to determine grain yield (GY), reported at $130 \mathrm{~g} \cdot \mathrm{kg}^{-1}$ moisture concentration. The above-ground dry matter or wheat biomass (TDM) was determined from hand samples taken from two $1-\mathrm{m}^{2}$ quadrats of each plot at harvest.

\subsection{Data Analysis}

\subsubsection{Analysis of Variance}

All data were subjected to an analysis of variance using the procedures of SAS [24-26] for each variable. The analysis of variance was carried out for each year as well as over years. This combined variance analysis provided an overview of the magnitude of variation among years and treatments and especially the treatment * year interaction. When the F-test indicated statistical significance at $5 \%$, treatment means were separated by Least Significant Difference (LSD) test.

\subsubsection{Stability Analysis}

The significance of the interactions of treatment $x$ years can be interpreted using stability analysis. It is the linear regression of treatment yield on the year environment mean yield (average yield of all comparable treatments in a given year). This analysis is carried out without the use of data transformation. High yield stability usually refers to a crop's ability to perform consistently, whether at high or low yield levels, across a wide range of environments [27]. The regression tests were carried using SAS statistical package. A regression coefficient (slope, b) $>1$ is indicative of below average stability while a regression coefficient $<1$ is indicative of above average stability. Specific tillage-residue management and cropping systems can be considered stable if variation is low over years (i.e. Low Coefficients of Variation, CVs) [28].

\section{Results}

This field study assessed average wheat yields and temporal yield variability over a 9-year period in agricultural management systems that are part of a long-term cropping systems experiment at Sidi El Aydi Station (SEAS) in south-western Morocco.

Table 5 presents pooled (averaged over the nine years) analysis of variance of the experiment. Significant year effects were noticed for all management systems. Table 5 indicates significant Tillage $\mathrm{x}$ years and Rotation $\mathrm{x}$ years interactions $(\mathrm{P}<0.001)$ and showed the influence of changes in environments on the yield performance of the various tillage-residue management and cropping systems evaluated.

It is also worth noting that during the course of the experiment, soil quality attributes have changed or been altered by tillage, residue management and cropping systems. These modifications in soil porosity and organic matter, stable aggregates, nitrogen and phosphorus contents of the soil surface $(0-5 \mathrm{~cm})$ were reported by several authors $[29,30]$.

Table 5. Degree of freedom and Mean square error (MSE) for wheat grain and biomass yields as affected by year, tillage-residue management and cropping systems (Combined ANOVA) at Sidi El Aydi (Morocco); 1994-2003.

\begin{tabular}{lccc}
\hline \multirow{2}{*}{ Source of variation } & df & \multicolumn{2}{c}{ MSE } \\
\cline { 3 - 4 } & & Biomass & Grain yield \\
\hline Year (Y) & 8 & 735.4 & 99.47 \\
Block (B) & 2 & 32.89 & 2.53 \\
Error a & 16 & 5.159 & 0.68 \\
Rotation (R) & 4 & 5.159 & 16.088 \\
$\mathrm{Y} * \mathrm{R}$ & 32 & 112.8 & 2.018 \\
Error b (Y * $\mathrm{R} * \mathrm{~B})$ & 72 & 0.134 & 0.028 \\
Tillage-residue management $(\mathrm{T})$ & 3 & 18.32 & 2.79 \\
$\mathrm{Y} * \mathrm{~T}$ & 24 & 5.6 & 1.25 \\
$\mathrm{R} * \mathrm{~T}$ & 12 & $0.18 \mathrm{~ns}$ & $0.03 \mathrm{~ns}$ \\
$\mathrm{Y} * \mathrm{R} * \mathrm{~T}$ & 96 & $0.09 \mathrm{~ns}$ & $0.019 \mathrm{~ns}$ \\
Error c & 270 & 0.12 & 0.025 \\
\hline
\end{tabular}

ns $=$ Not significant. All other factors or interactions were highly significant $(\mathrm{P}<0.001)$. 


\subsection{Growing Conditions}

The semiarid climate, gently sloping topography and slowly permeable clay soils are important characteristics of the western plains of Morocco. Humid winters and dry summers characterize the climate of Sidi El Aydi (Chaouia). Table 2 gives wheat growing season monthly rainfall for the study period (1994-2003) and for the long-term records (1967-2003).

As reported in Table 2, during the nine years of the experiment, about $77 \%$ of the $265.5 \mathrm{~mm}$ mean growing season rainfall (GSR) for wheat occurs from November through February and about 23\% from March to May. However, for the 1967-2003 records, the two phases received 70 and $30 \%$ amount of rainfall for the two growing periods respectively. Exceptionally, in 1997-1998 and 2000-2001, most rainfall occurred in the period from November to January (94\%), leaving the rest of the growing season almost dry. At the opposite, in the driest year (1994-1995), almost 60\% of received rainfall occurred in the reproductive period of wheat (Table 2). The wettest year (1996-1997) corresponded to the average year with 82 and $18 \%$ of rainfall received in the vegetative and reproductive phase, respectively.

The most common and widespread of the country's natural hazards is drought. It is a country-spread problem seriously influencing wheat production and quality. Drought may occur early in the season as in 1998-1999, in mid-season as in 1996-1997, 1999-2000 and 20002001 or in later season as in 1997-1998. It may also occur at combination of stages such as in 1994-1995. Weather conditions in the nine seasons from 1994-1995 to 2002-2003 spanned much of the variability, which characterizes rainfall records for this area (Table 2). The growing-season rainfall (GSR) for the 9-year study period averaged $265.5 \mathrm{~mm}$ per year, $43.4 \mathrm{~mm}$ lower than the long-term average; thus conditions were unfavourable for dryland cropping. In fact, the deviation of GSR from the long-term rainfall average varied from -195.4 to +131.1 , which shows the large variation of rainfall pattern of Chaouia region (Table 2).

Growing season rainfall varied from as low as 113.5 $\mathrm{mm}$ (1994-1995) to $440 \mathrm{~mm}$ (1995-1996), with an average over the 9 years of $265.5 \mathrm{~mm}$ (Table 2). Only 3 years (1995-1996, 1996-1997, and 2002-2003) were above long-term average (1967-2003) that is $308.9 \mathrm{~mm}$. Hence, differences in rainfall contributed to different yield responses, as shown by the various treatment * year interactions (Table 5).

\subsection{Wheat Yields}

Seasonal and annual variations in rainfall strongly influ- enced wheat responses to tillage-residue management and cropping systems in this experiment. Rainfall amount and distribution are critical for proper wheat performances. Moisture stress at critical physiological stages could inhibit crown roots, reduce effective tillers, diminish wheat vegetative growth and number of grains per ear and cause poor grain-filling. Generally, in semi-arid areas, wheat under No-till conditions are under high available water content during most the growing season and lower temperatures [16].

The long-term effects of tillage and wheat residue management on wheat grain yields are summarized in Table 6. Complete crop failure was observed in the first and the sixth year of the experiment for all tillage-residue management systems and rotations. At the research site, cumulative growing season rainfall was 113.5 and 152.4 $\mathrm{mm}$ for the two years, respectively. There is a need of at least $190 \mathrm{~mm}$ of moisture during the wheat growing season to garanty wheat grain production in semi-arid regions as noted by [14].

\subsubsection{Tillage-Residue Management Effects}

When averaging over the nine years, No-tillage system in its 3 variants guarantied higher grain yields than the conventional tillage system (Table 6). Within the 3 variants of residue cover, it is clear that $\mathrm{NT}_{\mathrm{p}}$ should be the logical choice for mixed farming systems, since it permitted identical yield as $\mathrm{NT}_{\mathrm{m}}$. This is due to the need to export partially biomass for livestock feeding. It is also important to Note that grain yield was significantly lower under CT than bare No-till $\left(\mathrm{NT}_{\mathrm{r}}\right)$. Hence, it is evidently recommended to support No-tillage for higher and stable yields of wheat; which is a leeway to adapt under contrasting climates.

The effect of tillage system was significant in all years at the exception of 1996-1997 and 1999-2000. In addition, CT was permitting higher yields than NT in one year (1997-1998) (Table 6). Residue management under NT did not show effects in 4 contrasting years (19941995; 1996-1997; 1998-1999 and 1999-2000). In the other 5 years, either $\mathrm{NT}_{\mathrm{p}}$ or $\mathrm{NT}_{\mathrm{m}}$ or both out-yielded $\mathrm{NT}_{\mathrm{r}}$. Hence, when analyzing the performances of wheat yield under the various tillage-residue management options for the 9-year, it is clear that No-tillage either equalled or exceeded CT. Particularly for $\mathrm{NT}_{\mathrm{p}}$, wheat yields were largely greater than CT in 1995-1996; 2000-2001 and 2002-2003 as shown by the high yield ratios of Table 6 . These trends were also reported by [13]. However, [31] did not find any difference between the two tillage systems in Northern Syria for barley production.

The type of drill used in No-tillage systems changes the growing environment and can thereby impact the 


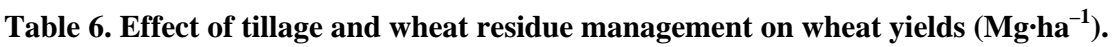

\begin{tabular}{|c|c|c|c|c|c|c|c|c|c|c|c|}
\hline & 1994-1995 & 1995-1996 & 1996-1997 & 1997-1998 & 1998-1999 & $1999-2000$ & $2000-2001$ & $2001-2002$ & $2002-2003$ & Average & $\begin{array}{l}\text { Yield }^{\mathrm{a}} \\
\text { ratio }\end{array}$ \\
\hline $\mathrm{NT}_{\mathrm{r}}$ & 0 & $3.37 \mathrm{c}$ & $2.69 a$ & $1.11 \mathrm{~d}$ & $2.98 \mathrm{a}$ & $0.26 a$ & $1.91 \mathrm{~b}$ & $3.25 \mathrm{bc}$ & 3.32a & $2.10 B$ & \\
\hline $\mathrm{NT}_{\mathrm{p}}$ & 0 & $3.57 \mathrm{~b}$ & $2.72 \mathrm{a}$ & $1.31 \mathrm{c}$ & 2.93ab & $0.28 a$ & $2.30 \mathrm{a}$ & $3.42 a$ & $3.36 a$ & $2.21 A$ & \\
\hline $\mathrm{NT}_{\mathrm{m}}$ & 0 & $3.94 \mathrm{a}$ & $2.65 a$ & $1.62 b$ & $2.86 \mathrm{ab}$ & $0.26 \mathrm{a}$ & $2.27 \mathrm{a}$ & 3.31ab & $2.94 \mathrm{~b}$ & $2.21 A$ & \\
\hline $\mathrm{CT}$ & 0 & $2.60 d$ & $2.73 a$ & $1.75 \mathrm{a}$ & $2.76 \mathrm{c}$ & $0.28 \mathrm{a}$ & $1.01 \mathrm{c}$ & $3.16 c$ & $2.85 b$ & $1.90 \mathrm{C}$ & \\
\hline Average & $0 \mathrm{~F}$ & $3.37 \mathrm{~A}$ & $2.70 \mathrm{C}$ & $1.44 \mathrm{E}$ & $2.88 \mathrm{BC}$ & $0.27 \mathrm{~F}$ & $1.87 \mathrm{D}$ & $3.29 \mathrm{~A}$ & $3.11 \mathrm{AB}$ & 2.10 & \\
\hline $\mathrm{NT}_{\mathrm{r}} / \mathrm{CT}$ & - & 1.30 & 0.98 & 0.63 & 1.08 & 0.93 & 1.89 & 1.03 & 1.16 & & 1.13 \\
\hline $\mathrm{NT}_{\mathrm{p}} / \mathrm{CT}$ & - & 1.37 & 1.00 & 0.75 & 1.06 & 1.00 & 2.28 & 1.08 & 1.18 & & 1.21 \\
\hline $\mathrm{NT}_{\mathrm{m}} / \mathrm{CT}$ & - & 1.51 & 0.97 & 0.93 & 1.04 & 0.93 & 2.25 & 1.05 & 1.03 & & 1.21 \\
\hline
\end{tabular}

a the ratio of NT to CT not including the 1994-95 year in averaging over years. $\mathrm{NT}_{\mathrm{r}}=$ Full removal of flat residues in no-tillage, $\mathrm{NT}_{\mathrm{p}}=\mathrm{Partial}_{\mathrm{removal}}$ of flat residues in no-tillage, $\mathrm{NT}_{\mathrm{m}}=$ Total maintenance of flat residues in no-tillage, $\mathrm{CT}=$ Conventional tillage. In the column (small or italic letters) or row (capital letters), means followed by the same letters do not differ by LSD test at $\mathrm{p}=0.05$.

physiology of the crop. These facts may have some negative outcomes on crop growth. Use of the double-disk type drill, during the first 3 years, had various disadvantages, including surface application of P fertilizer, weak penetration through thick residues and dry soil, and inability to adequately cut through residues. Under $\mathrm{NT}_{\mathrm{m}}$, seeds were also in close contact with the straw which reduced early vigour and growth [16]. The high residue cover could delay emergence, seedling development and retard tillering of wheat seeded with disk drills [32].

The hoe-type drill, used during the 6 last years, produced more soil disturbance along seeding row than TYE drill, and was needed for better seeding of wheat into dry soil surface. It also permitted localisation of $\mathrm{P}$ and $\mathrm{N}$ fertilisers in proximity to the seeds, which helped wheat to grow more vigorously and produce more biomass $[33,34]$.

\subsubsection{Cropping System's Effects}

Wheat is an important part of the cropping system in semiarid Morocco. Yielding of dryland wheat depends enormously on the amount of profile-stored water and/or precipitation during the growth period. Wheat is very responsive to crop rotation. The long-term effects of cropping systems on wheat grain are shown in Table 7.

The continuous wheat rotation had the lowest yields irrespective of the treatment and years (Table 7). Not including 1994-1995, wheat yields varied from as low as $0.05 \mathrm{Mg} /$ ha under WLF in 1999-2000 to as high as 3.83 $\mathrm{Mg} / \mathrm{ha}$ under WMF in the year (2001-2002).

On average, it is shown from Table 7 that wheat yields are the highest under WF; WBF and WLF. Wheat yield under WMF is intermediary and higher than CW. The WLF could be more performing if Not the low wheat yielding in 1999-2000 due to residual effect of herbicide
(Simazine) used for controlling weeds in lentil. The percent increase in wheat yields when comparing biennial or triennial rotations to $\mathrm{CW}$ varied from $84 \%$ under WF to 59\% under WMF (Table 7).

\subsection{Above-Ground Biomass Yield}

Grain yield is the product of plant biomass and partitioning of that biomass to the harvested components. Hence, in uncovering the impact of tillage systems on yield, it would be necessary to determine whether NT limits plant biomass accumulation or Not. In other terms, although much work has been conducted on the impact of NT on wheat yield, there is little information on the impact of NT on above-ground biomass accumulation. A reduction in biomass may occur due to poor stand establishment or reduced tillering [16].

\subsubsection{Tillage-Residue Management's Effects}

In Table 8, tillage and residue management system's effects on wheat above-ground biomass are presented. NT production systems did not generally reduce the ability of wheat cultivars to accumulate biomass. The NT treatment impacted biomass yields of wheat, but this response was dependent on the environment. According to Table 8, the three variants of NT helped accumulation of higher biomass than CT. It is also reported in the same Table that biomass yield increases with residue cover under the soil, on average and by year. At the exception of 1996-1997 where $\mathrm{NT}_{\mathrm{p}}$ was permitting higher biomass yield of wheat, $\mathrm{NT}_{\mathrm{m}}$ was showing the highest biomass. In fact, it has reached $12.67 \mathrm{Mg} \cdot \mathrm{ha}^{-1}$ in 1995-1996. Not considering the driest year of 1994-95, in other dry years ( $<200 \mathrm{~mm}$ ), NT out-yielded CT by 1.11 to 2.07 as shown in Table 8. Especially, NT biomass yields were two 


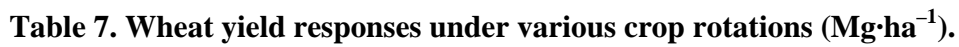

\begin{tabular}{|c|c|c|c|c|c|c|c|c|c|c|c|}
\hline $\begin{array}{l}\text { Crop } \\
\text { rotation }\end{array}$ & 1994-1995 & 1995-1996 & 1996-1997 & 1997-1998 & 1998-1999 & $1999-2000$ & $2000-2001$ & 2001-2002 & $2002-2003$ & $\begin{array}{l}\text { Yield } \\
\text { ratio }^{\mathrm{a}}\end{array}$ & Average \\
\hline CW & 0 & 3.13d & $1.98 \mathrm{~d}$ & $0.94 \mathrm{e}$ & $1.10 \mathrm{c}$ & $0.29 \mathrm{c}$ & $0.93 d$ & $2.60 \mathrm{~d}$ & $1.82 \mathrm{c}$ & 1.00 & $1.42 D$ \\
\hline WF & 0 & $3.71 b$ & $2.90 \mathrm{~b}$ & $2.05 a$ & $3.20 \mathrm{~b}$ & $0.44 a$ & $2.24 \mathrm{a}$ & $3.21 \mathrm{c}$ & $3.28 b$ & 1.84 & $2.34 A$ \\
\hline WBF & 0 & $2.86 \mathrm{e}$ & $3.22 \mathrm{a}$ & $1.44 \mathrm{c}$ & $3.71 \mathrm{a}$ & $0.31 b$ & $2.12 b$ & $3.38 b$ & $3.65 a$ & 1.76 & $2.30 A B$ \\
\hline WMF & 0 & 3.39c & $2.64 c$ & $1.05 \mathrm{~d}$ & $3.24 \mathrm{~b}$ & $0.26 \mathrm{~d}$ & $1.96 \mathrm{c}$ & $3.83 a$ & $3.19 b$ & 1.59 & $2.17 C$ \\
\hline WLF & 0 & $3.76 a$ & $2.73 c$ & $1.73 \mathrm{~b}$ & $3.16 b$ & $0.05 \mathrm{e}$ & $2.10 \mathrm{~b}$ & $3.41 \mathrm{~b}$ & $3.65 a$ & 1.63 & $2.29 B$ \\
\hline Average & $0 \mathrm{~F}$ & 3.37A & $2.70 \mathrm{C}$ & $1.44 \mathrm{E}$ & 2.88BC & $0.27 \mathrm{~F}$ & $1.87 \mathrm{D}$ & $3.29 \mathrm{~A}$ & 3.11AB & & 2.10 \\
\hline
\end{tabular}

a ratio of wheat yields under fallow based rotations to continuous wheat for the average of 1996-2003. CW = Continuous Wheat, $\mathrm{WF}=\mathrm{Wheat}-\mathrm{Fallow}$, WBF $=$ Wheat-Barley-Fallow, WMF = Wheat-Maize-Fallow, WLF = Wheat-Lentil-Fallow. In the column (small or italic letters) or row (capital letters), means followed by the same letters do not differ by LSD test at $\mathrm{p}=0.05$.

Table 8. Tillage and residue management system's effects on wheat above-ground biomass (Mg·ha $\left.{ }^{-1}\right)$.

\begin{tabular}{|c|c|c|c|c|c|c|c|c|c|c|c|}
\hline $\begin{array}{c}\text { Tillage-residue } \\
\text { treatment }\end{array}$ & $\begin{array}{l}1994- \\
1995\end{array}$ & 1995-1996 & 1996-1997 & $\begin{array}{l}1997- \\
1998\end{array}$ & 1998-1999 & 1999-2000 & $\begin{array}{l}2000- \\
2001\end{array}$ & 2001-2002 & 2002-2003 & Average & $\begin{array}{l}\text { Yield } \\
\text { ratio }^{\text {a }}\end{array}$ \\
\hline $\mathrm{NT}_{\mathrm{r}}$ & $0.15 \mathrm{c}$ & $11.64 \mathrm{~b}$ & $9.91 b$ & $3.01 \mathrm{c}$ & 9.79a & $5.07 \mathrm{c}$ & $3.96 b$ & $6.02 \mathrm{~d}$ & $6.49 \mathrm{~b}$ & $6.23 C$ & \\
\hline $\mathrm{NT}_{\mathrm{p}}$ & $0.41 \mathrm{~b}$ & $11.20 \mathrm{c}$ & $10.65 a$ & $3.56 \mathrm{~b}$ & $9.60 \mathrm{a}$ & $5.31 b$ & $4.80 \mathrm{a}$ & $6.48 \mathrm{c}$ & $6.74 a$ & $6.52 B$ & \\
\hline $\mathrm{NT}_{\mathrm{m}}$ & $0.52 a$ & $12.67 \mathrm{a}$ & $9.59 \mathrm{~b}$ & $4.42 \mathrm{a}$ & $9.62 a$ & $5.35 a$ & $4.75 a$ & $6.92 a$ & 6.53ab & $6.71 A$ & \\
\hline $\mathrm{CT}$ & $0.19 \mathrm{c}$ & 9.99d & $9.93 b$ & $4.68 a$ & $8.64 b$ & $4.27 d$ & $2.29 \mathrm{c}$ & $6.80 \mathrm{~b}$ & $6.03 c$ & 5.87D & \\
\hline Average & $0.32 \mathrm{~F}$ & 11.37A & $10.02 \mathrm{~B}$ & $3.92 \mathrm{E}$ & $9.41 \mathrm{~B}$ & 4.99D & $3.95 E$ & $6.55 \mathrm{C}$ & $6.45 \mathrm{C}$ & 6.33 & \\
\hline $\mathrm{NT}_{\mathrm{r}} / \mathrm{CT}$ & 0.79 & 1.16 & 0.99 & 0.64 & 1.13 & 1.19 & 1.73 & 0.93 & 1.08 & & 1.07 \\
\hline $\mathrm{NT}_{\mathrm{p}} / \mathrm{CT}$ & 2.16 & 1.12 & 1.07 & 0.76 & 1.11 & 1.24 & 2.10 & 0.95 & 1.12 & & 1.29 \\
\hline $\mathrm{NT}_{\mathrm{m}} / \mathrm{CT}$ & 2.74 & 1.27 & 0.97 & 0.94 & 1.11 & 1.25 & 2.07 & 1.02 & 1.08 & & 1.38 \\
\hline
\end{tabular}

${ }^{a}$ the wheat above-ground biomass ratio of $\mathrm{NT}$ to $\mathrm{CT}$ in averaging over years. $\mathrm{NT}_{\mathrm{r}}=$ Full removal of flat residues in no-tillage, $\mathrm{NT}_{\mathrm{p}}=\mathrm{Partial}$ removal of flat residues in no-tillage, $\mathrm{NT}_{\mathrm{m}}=$ Total maintenance of flat residues in no-tillage, $\mathrm{CT}=$ Conventional tillage. In the column (small and italic letters) or row (capital letters), means followed by the same letters do not differ by LSD test at $\mathrm{p}=0.05$.

times higher than CT in 2000-2001 where the wheat was under severe droughts in mid- and late seasons. However, in wet years (>400 mm); NT/CT varied from 0.97 to 1.27 . In general, yield advantage of NT over CT increased due to residue cover level (yield ratios of $1.07 ; 1.29$ and 1.38 for $\mathrm{NT}_{\mathrm{r}} ; \mathrm{NT}_{\mathrm{p}}$ and $\mathrm{NT}_{\mathrm{m}}$ ).

\subsubsection{Cropping System's Effects}

Rotation effects on above-ground wheat biomass for the nine years are exhibited in Table 9. Cropping systems tested in this trial respond consistently among environments and there was a strong interaction among environments or years and cropping system $(\mathrm{P}<0.001)$ (Tables 4 and 9 ).

From results presented in Table 9, continuous wheat (CW) permitted the lowest yearly average biomass yield among the cropping systems tested in this experiment. However, especially in 1995-1996 and 1997-1998 and in 2001-02, CW out yielded WBF and WLF respectively.
WF rotation was best performing in year of severe drought (i.e. 1997-1998) as compared to other cropping systems. WF and WBF surpassed all other rotations in adapting wheat to produce and accumulate dry matter in 19992000 where GRS was only $152 \mathrm{~mm}$. Biomass yield advantage for biennial and triennial rotation over CW varied from $48 \%$ to $76 \%$.

It is clear from this analysis that farmers could choose either WF or WBF as appropriate cropping systems. However, for an intimate integration of grain and livestock productions, WBF would a desired and reliable choice since it is including a dual purpose crop, barley. Other cropping sequences including forage crops are also of relevance to dryland farmers if well managed [4].

\subsection{Yield-Rainfall Relationships}

Table 10 presents the regression coefficients of linear relations between yields and GSR, vegetative phase 


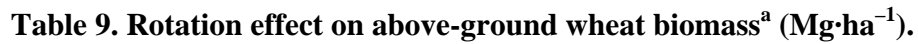

\begin{tabular}{|c|c|c|c|c|c|c|c|c|c|c|c|}
\hline Rotation & 1994-1995 & 1995-1996 & 1996-1997 & 1997-1998 & 1998-1999 & $1999-2000$ & $2000-2001$ & 2001-2002 & $2002-2003$ & $\begin{array}{l}\text { Biomass } \\
\text { ratio }^{b}\end{array}$ & Average \\
\hline CW & $0.27 b$ & $11.38 \mathrm{~d}$ & $7.50 \mathrm{e}$ & $3.16 \mathrm{cb}$ & $3.72 \mathrm{c}$ & $3.24 d$ & $1.96 \mathrm{e}$ & $6.04 d$ & $4.04 \mathrm{c}$ & 1 & $4.59 E$ \\
\hline WF & $0.35 \mathrm{ab}$ & $11.74 a$ & $10.98 \mathrm{~b}$ & $6.85 a$ & $10.56 \mathrm{~b}$ & $6.22 a$ & 4.65a & $6.54 \mathrm{c}$ & $6.62 b$ & 1.76 & $7.17 A$ \\
\hline WBF & $0.41 \mathrm{a}$ & $10.66 \mathrm{e}$ & $12.00 \mathrm{a}$ & $2.42 \mathrm{c}$ & $12.16 a$ & $6.07 a$ & $4.55 b$ & $6.79 b$ & 7.52a & 1.69 & $6.95 B$ \\
\hline WMF & $0.25 b$ & $11.45 \mathrm{c}$ & $9.59 d$ & $3.85 b$ & $10.45 b$ & $3.80 \mathrm{c}$ & $4.06 \mathrm{~d}$ & $7.48 a$ & $6.38 b$ & 1.48 & $6.37 D$ \\
\hline WLF & 0.31ab & $11.64 \mathrm{~b}$ & $10.03 c$ & $3.30 \mathrm{~b}$ & $10.17 b$ & $5.62 \mathrm{~b}$ & $4.51 \mathrm{c}$ & $5.92 \mathrm{e}$ & 7.68a & 1.58 & $6.57 C$ \\
\hline Average & $0.32 \mathrm{~F}$ & 11.37A & $10.02 \mathrm{~B}$ & 3.92E & $9.41 \mathrm{~B}$ & 4.99D & $3.95 \mathrm{E}$ & $6.55 \mathrm{C}$ & $6.45 \mathrm{C}$ & & 6.33 \\
\hline
\end{tabular}

${ }^{\mathrm{a}}$ Wheat plants were harvest at heights of $10-15 \mathrm{~cm}$. ${ }^{\mathrm{b}}$ Ratio of wheat biomass yields under fallow based rotations to continuous wheat for the average of 1995-2003. CW = Continuous Wheat, WF $=$ Wheat-Fallow, WBF $=$ Wheat-Barley-Fallow, WMF $=$ Wheat-Maize-Fallow, WLF $=$ Wheat-Lentil-Fallow. In the column (small or italic letters) or row (capital letters), means followed by the same letters do not differ by LSD test at $\mathrm{p}=0.05$.

Table 10. Regression coefficients for grain yield and growing season (GSR), vegetative phase (VPR) and reproductive phase (RPR) rainfall by tillage-residue management and cropping system.

\begin{tabular}{cllc}
\hline & GSR & VPR & RPR \\
\hline Cropping system & & & 0.714 \\
CW & 0.869 & 0.707 & 0.451 \\
WF & 0.753 & 0.574 & 0.393 \\
WBF & 0.620 & 0.529 & 0.578 \\
WMF & 0.643 & 0.663 & 0.482 \\
WLF & 0.726 & & 0.539 \\
& Tillage and residue management system & 0.617 & 0.516 \\
NT & 0.507 & 0.630 & 0.538 \\
NT & 0.709 & 0.675 & 0.532 \\
CT & 0.755 & 0.649 & \\
\hline
\end{tabular}

$\mathrm{NT}_{\mathrm{r}}=$ Full removal of flat residues in no-tillage, $\mathrm{NT}_{\mathrm{p}}=$ Partial removal of flat residues in no-tillage, $\mathrm{NT}_{\mathrm{m}}=$ Total maintenance of flat residues in no-tillage, CT $=$ Conventional tillage. $\mathrm{CW}=$ Continuous Wheat, $\mathrm{WF}=$ Wheat-Fallow, WBF $=$ Wheat-Barley-Fallow, WMF=Wheat-Maize-Fallow, WLF = Wheat-Lentil-Fallow.

rainfall (VPR) and reproductive phase rainfall (PPR) as explained in Table 5. Wheat yields are more dependent on GSR and vegetative phase rainfall (VPR) as regression determinants are higher. $\mathrm{CW}$ is more responding to seasonal variability of rainfall than the other cropping systems. This confirms the stressed environment characterizing continuous cropping. This result can be explained by the low yields of this cropping system. In other terms, water conditions under fallow based rotation helped wheat to depend less on late rainfall and hence avoid late or mid-drought [14]. This is mainly due to available water stored in soil profile from previous year's rainfall. This explains the stabilising benefit from fallow in semiarid areas. Especially, from Tables 8 and 10, un- der wheat-fallow, wheat is better user of rainfall pattern or distribution and hence avoiding intermittent drought or water deficit than in other cropping systems.

From Table 10, the relation between yield and rainfall parameters is positively correlated to residue level under NT, mainly for GSR and VPR. CT is found intermediate between $\mathrm{NT}_{\mathrm{m}}$ and $\mathrm{NT}_{\mathrm{p}}$ in responding to rainfall parameters in a semiarid area. This can explain that residue management is equivalent to water management in dry areas under NT.

\subsection{Stability Analysis of Grain Yields}

Soil management systems have substantial impacts on ecosystem processes that contribute to annual crop yield 
variability. Understanding and capitalizing on wheat yield time-variability or stability has become one of the most intriguing problems in current NT production research in Morocco. An ideal agricultural technology or system is one that achieves the highest yield across multi-environments. Wheat yields under no-tillage were shown to increase with respect to other traditional or conventional tillage systems. Slopes with $b<1.0$ indicate better adaptation to poor environments, while genotypes with " $\mathrm{b}>1.0$ " are best used in superior environments as suggested by [35].

Stability analysis provides useful parameter estimates when numbers of treatments and environments considered in the analysis are sufficiently large [36], which is the case in this study. The regression of treatment aver- age yield on the environmental index resulted in regression coefficients shown in Table 11.

The yield potential of the No-tillage systems was generally superior to conventional tillage systems, but there was no yield stability sacrificed to achieve the greater yield potential. Table 11 gives the regression coefficient (b) values of the tillage-residue management and cropping systems developed from linear regression analysis.

Tillage-residue management treatments have " $\mathrm{b}$ " valued ranging from 0.90 to 1.05 , while for the cropping systems, "b" varied from 0.69 to 1.09 . The No-tillage treatments have a slope close to unity which shows an average response to environmental conditions, as measured by the environment mean. In Figure 1, WF, WBF and WMF are showing identical linear trends in terms of

Table 11. Stability parameters for tillage—residue management and cropping systems based on grain yield data (1994-2003).

\begin{tabular}{ccccc}
\hline & Slope $b$ & t-stat & R-Square & CV \% \\
\hline $\mathrm{NT}_{\mathrm{r}}$ & 1.006 & Tillage-Residue Management & & 63.84 \\
$\mathrm{NT}_{\mathrm{p}}$ & 1.050 & 90.18 & 0.988 & 61.63 \\
$\mathrm{NT}_{\mathrm{m}}$ & 1.042 & 44.00 & 0.987 & 60.81 \\
$\mathrm{CT}$ & 0.900 & 27.74 & 0.968 & 62.84 \\
& & 18.94 & 0.911 & 73.19 \\
$\mathrm{CW}$ & 0.686 & Cropping systems & 56.11 \\
WF & 1.084 & 10.75 & 0.790 & 61.82 \\
WBF & 1.085 & 30.63 & 0.967 & 65.70 \\
WMF & 1.048 & 19.55 & 0.926 & 63.39 \\
WLF & 1.095 & 35.54 & 0.986 & 671 \\
\hline
\end{tabular}

$\mathrm{CV}=$ Coefficient of Variation; $\mathrm{NT}_{\mathrm{r}}=$ Full removal of flat residues in no-tillage, $\mathrm{NT}_{\mathrm{p}}=$ Partial removal of flat residues in no-tillage, $\mathrm{NT}_{\mathrm{m}}=$ Total maintenance of flat residues in no-tillage, $\mathrm{CT}=$ Conventional tillage. $\mathrm{CW}=$ Continuous Wheat, $\mathrm{WF}=$ Wheat-Fallow, $\mathrm{WBF}=$ Wheat-Barley-Fallow, WMF $=$ Wheat-Maize-Fallow, WLF $=$ Wheat-Lentil-Fallow.

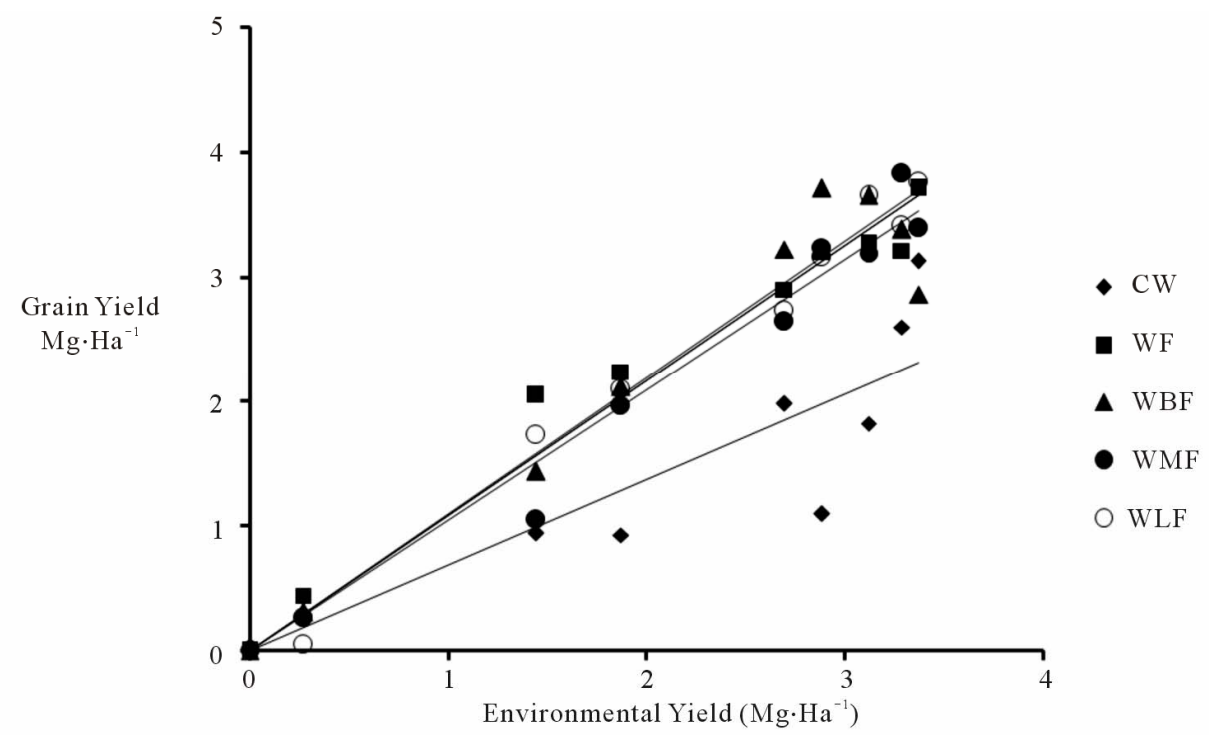

Figure 1. Yield stability regression plots for cropping systems. 
grain yield and environment relationships. WLF is an intermediate situation. Continuous wheat system is more practical in low rainfall areas and harsh environments as explained by low b. As shown in Figure 2, all 3 variants of NT exhibited a higher linear tendency between yield and environment as compared to CT.

One measure of yield variability is the coefficient of variation of yield (Table 11). It is shown that $\mathrm{NT}_{\mathrm{r}}$ and CT among tillage treatments and CW and WMF among cropping sequences are having grain yield highly variable than the other treatments. This maintains the conclusion that NT associated with residue cover and conservation cropping system (WF) are most likely to adapt to conditions of Moroccan semiarid areas.

Following the method of [35], the environmental mean of each tillage or cropping system was placed on the $x$ axis and the regression coefficient (yield stability) was placed on the $y$ axis to determine the relationship among yield and yield stability (Figure 3 ). This figure shows that the stability coefficient " $b$ " increases with improvement in environments.

\section{Discussion}

From this long-term study, it can be concluded that production of winter wheat under No-tillage can have agronomic benefits over conventional tillage systems, although in some years it can result in lower yields. The important finding from this study is that No-tillage has to be adopted as a system, combining both direct seeding and retention of crop residues. It was concluded that Notill with stubble retained treatment was the best option in terms of higher and more efficient use of water

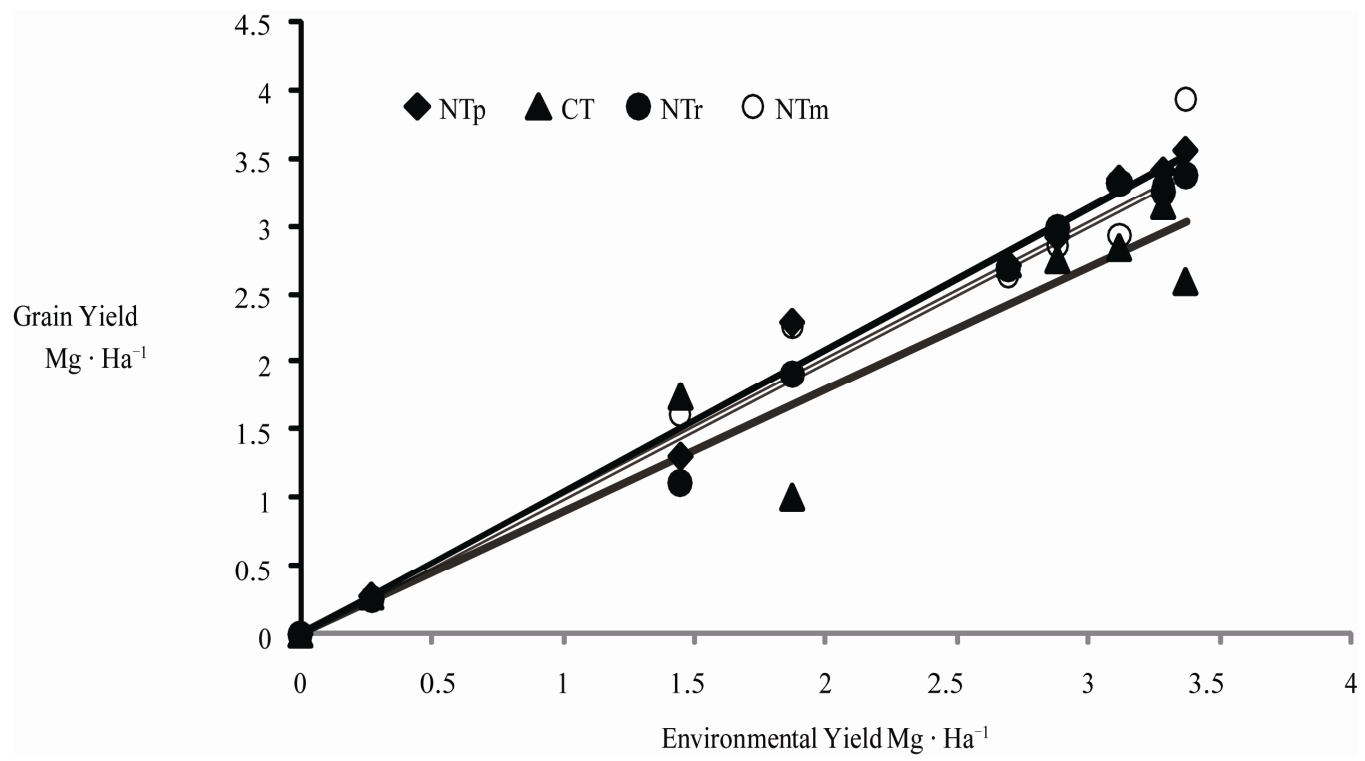

Figure 2. Yield stability regression plots for tillage-residue management systems.
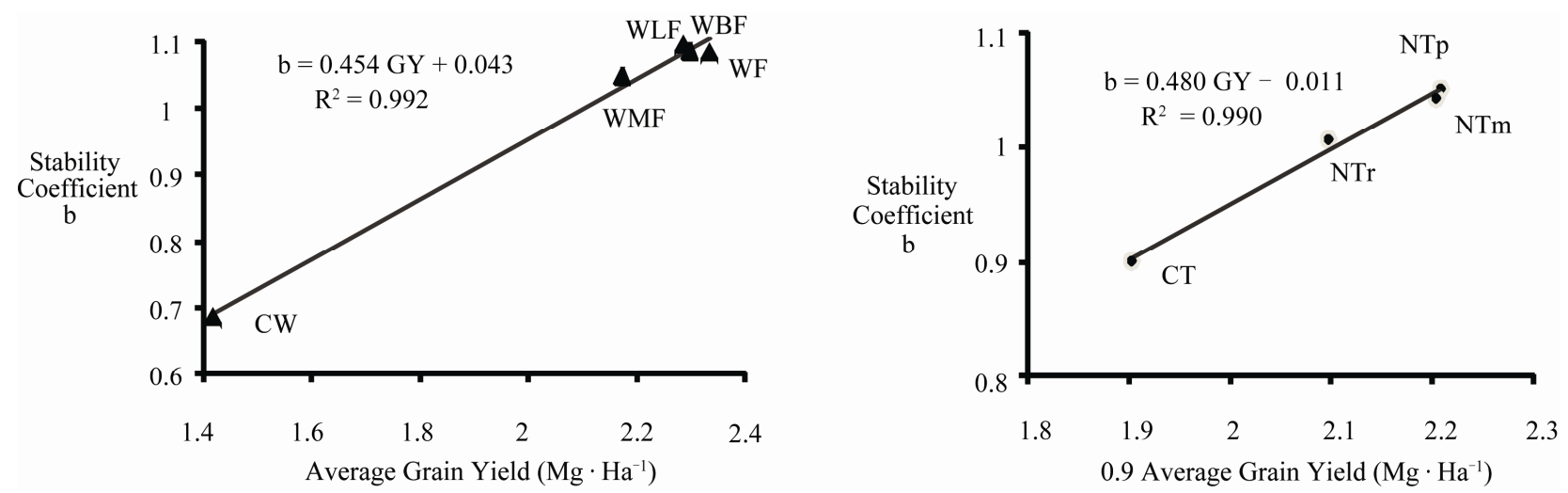

Figure 3. Stability regression coefficients plotted against the average environmental means of tillage-residue management and cropping systems. Stability regression coefficients were positively associated with yield. 
resources. Basically, $\mathrm{NT}_{\mathrm{p}}$ could be adopted in mixed crop-livestock systems of semiarid areas for the purpose of guarantying grain and feed.

Due to high grain and biomass production under NT, our results demonstrate also, the effectiveness of No-tillage with mulching in increasing rainfall use compared to the conventional tillage system and complete stubble removal under No-tillage in the semi-arid area of the Chaouia region. This is explained by wheat yield-rainfall relationships. In fact, residue retention under NT may have helped managing rainfall and carrying over soil moisture during the growth and development of wheat [37]. These possible good relations at the soil-residue interface vis-à-vis rainfall distribution are the main reasons for NT durability [13,38,39]. However, [13,40,41] reported that the major limitation to NT adoption by smallholder farmers is crop residue tradeoffs as soil amendments and livestock bedding, feed, and/or other off-field purposes and its low availability in dry areas and droughty years.

From this study, it can be concluded that either wheatfallow or wheat-barley-fallow can be promoted in semiarid areas but without any involvement of tillage systems. However, in semiarid Spain, authors found that wheatfallow is having low efficiency in increasing wheat yields $[37,38]$.

In this experiment, continuous wheat was found not durable vis-à-vis changing climate. The instability and low yields of continuous cereal have been reported by other authors from semiarid Mediterranean areas [42].

From the stability analysis, NT is adapting to most weather conditions occurred during the course of the experiment. In other words, this analysis indicated that yields in the No-tillage system were less influenced by adverse growing conditions than conventional tillage system, particularly under low rainfall. It is then, to the decision of farmers, to manage the cropping system according to technical and economical considerations:

- In harsh and economically constrained environments, continuous wheat can be used but is still risky. However, NT is an option for reducing such risk [43].

- In area of low rainfall (less than $300 \mathrm{~mm}$ ), wheatfallow is a requirement for stable grain production under NT [14]. However, this is not in agreement with other authors from dry areas in Spain [44] and US Great Plains [45].

- In areas of favorable rainfall and weather conditions, either lentil or barley could be used without additional reliance on row crop drills as for corn [15]. Better water supply for plants due to residue retention under NT could result in higher yield [46].

- In mixed farming, farmers may choose to include barley or other forage crops in the three year rotation to compensate for residue availability $[47,48]$.

Considering the advantages of NT wheat production systems to the region, such as earlier planting, reduced erosion and improved soil conservation and fertility, agronomic changes that bring about optimal yields under NT would be desirable. An in-depth understanding of the physiological factors, that in some years, limit yield under NT production systems may be useful in designing genetic [49] or agronomic measures [50] necessary to optimize yield under NT.

For a thorough understanding on impact of each decision, modeling is needed. Process-oriented crop growth models simulate the effects of genetics, management, weather and stresses on plant growth and yield [51].

In semiarid Mediterranean region, soil quality evaluation under conservation and conventional tillage systems should be prioritized [52] and carbon and nitrogen dynamics modeled under these contrasting systems [53]. These models will be the research focus in near future and for estimating environmental consequences of shifting to No-tillage technologies and conservation cropping sequences in both dry [54] and irrigated systems [55].

\section{Acknowledgements}

Special thanks to all postgraduate and graduate students who were involved in this project for different periods.

\section{REFERENCES}

[1] F. Garcia-Orenes, A. Cerda, J. Mataix-Solera, C. Guerrero, M. B. Bod, V. Arcenegui, R. Zornoza and J. G. Sempere, "Effects of Agricultural Management on Surface Soil Properties and Soil-Water Losses in Eastern Spain,” Soil \& Tillage Research, Vol. 106, No. 1, December 2009, pp. 117-123.

[2] J. P. Shroyer, J. Ryan, M. A. Monem and M. El Mourid, "Production of Fall-Planted Cereals in Morocco and Technology for Its Improvement,” Journal of Agronomic Education, Vol. 19, No. 1, 1990, pp. 32-40.

[3] C. H. Diaz-Ambrona and I. Minguez, "Cereal-Legume Rotations in a Mediterranean Environment: Biomass and Yield Production,” Field Crops Research, Vol. 70, No. 2, April 2001, pp. 139-151. doi:10.1016/S0378-4290(01)00132-0

[4] J. Ryan, E. de Pauw, H. Gomez and R. Mrabet, “Drylands of the Mediterranean Zone: Biophysical Resources and Cropping Systems,” In: G. A. Peterson et al., Eds., Dryland Agriculture, 2nd Edition, American Society of Agronomy Monograph No. 23, Madison, 2006, pp. 577-624.

[5] J. Álvaro-Fuentes, J. Lampurlanés and C. Cantero-Martínez, "Alternative Crop Rotations under Mediterranean NoTillage Conditions: Biomass, Grain Yield, and Water-Use Efficiency,” Agronomy Journal, Vol. 101, No. 5, September 2009, pp. 1227-1233. 


\section{doi:10.2134/agronj2009.0077}

[6] D. Akbolat, F. Evrendilek, A. Coskan and K. Ekinci, "Quantifying Soil Respiration in Response to Short-Term Tillage Practices: A Case Study in Southern Turkey," Acta Agriculturae Scandinavica, Section B-Plant Soil Science, Vol. 59, No. 1, January 2009, pp. 50-56.

[7] P. Angàs, J. Lampurlanés and C. Cantero-Martınez, “Tillage and N Fertilization Effects on N Dynamics and Barley Yield under Semiarid Mediterranean Conditions,” Soil \& Tillage Research, Vol. 87, No. 1, May 2006, pp. 59-71. doi:10.1016/j.still.2005.02.036

[8] L. Lopez-Bellido, R. J. Lopez-Bellido, J. E. Castillo and F. J. Lopez-Bellido, "Effects of Tillage, Crop Rotation, and Nitrogen Fertilization on Wheat under Rainfed Mediterranean Conditions,” Agronomy Journal, Vol. 92, No. 6, November 2000, pp. 1054-1063. doi:10.2134/agronj2000.9261054x

[9] M. Diaz-Zorita, J. H. Grove, L. Murdock, J. Herbeck and E. Perfect, "Soil Structural Disturbance Effects on Crop Yields and Soil Properties in a No-Till Production System,” Agronomy Journal, Vol. 96, No. 6, November 2004, pp. 1651-1659. doi:10.2134/agronj2004.1651

[10] P. G. Hunt, P. J. Bauer, T. A. Matheny and W. J. Busscher, "Crop Yield and Nitrogen Accumulation Response to Tillage of a Coastal Plain Soil," Crop Science, Vol. 44, No. 5, September 2004, pp.1673-1681. doi:10.2135/cropsci2004.1673

[11] S. Ozpinar and A. Cay, "Effect of Different Tillage Systems on the Quality and Crop Productivity of a ClayLoam Soil in Semi-Arid North-Western Turkey," Soil \& Tillage Research, Vol. 88, No. 1-2, July 2006, pp. 95-106. doi:10.1016/j.still.2005.04.009

[12] M. Mazzoncini, C. Di Bene, A. Coli, D. Antichi, M. Petri and E. Bonari, "Rainfed Wheat and Soybean Productivity in a Long-Term Tillage Experiment in Central Italy," Agronomy Journal, Vol. 100, No. 5, September 2008, pp. 1418-1429. doi:10.2134/agronj2007.0173

[13] S. B. Moussa-Machraoui, F. Errouissi, M. Ben-Hammouda and S. Nouira, "Comparative Effects of Conventional and No-Tillage Management on Some Soil Properties under Mediterranean Semi-Arid Conditions in Nordwestern Tunisia,” Soil \& Tillage Research, Vol. 106, No. 2, January 2010, pp. 247-253. doi:10.1016/j.still.2009.10.009

[14] A. Bouzza, "Water Conservation in Wheat Rotations under Several Management and Tillage Systems in Semiarid Areas,” Ph.D. Dissertation, University of NebraskaLincoln, Omaha, 1990.

[15] M. Kacemi, "Water Conservation, Crop Rotations, and Tillage Systems in Semiarid Morocco," Ph.D. Dissertation, Colorado State University, Fort Collins, 1992.

[16] R. Mrabet, “Crop Residue Management and Tillage Systems for Water Conservation in a Semiarid Area of Morocco,” Ph.D. Dissertation, Colorado State University, Fort Collins, 1997.

[17] R. Mrabet, N. Saber, A. El-Brahli, S. Lahlou and F. Bes- sam, "Total, Particulate Organic Matter and Structural Stability of a Calcixeroll Soil under Different Wheat Rotations and Tillage Systems in a Semiarid Area of Morocco,” Soil \& Tillage Research, Vol. 57, No. 4, January 2001, pp. 225-235. doi:10.1016/S0167-1987(00)00180-X

[18] R. Mrabet, K. Ibno-Namr, F. Bessam and N. Saber, "Soil Chemical Quality Changes and Implications for Fertilizer Management after 11 Years of No-Tillage Wheat Production Systems in Semiarid Morocco,” Land Degradation \& Development, Vol. 12, No. 6, November/December 2001, pp. 505-517. doi:10.1002/ldr.464

[19] R. Balaghi, M. Jlibene, B. Tychon and R. Mrabet, "Gestion du Risque de Sécheresse Agricole au Maroc," Sécheresse, Vol. 18, No. 3, 2007, pp.169-176.

[20] R. Lahmar, “Opportunités et Limites de l’Agriculture de Conservation en Méditerranée. Les Enseignements du Projet KASSA,” Options Méditerranéennes, Série A, Vol. 69, 2006, pp.11-18.

[21] A. Benmahammed, H, Nouar, L. Haddad, Z. Laala, O. Abdelmalek and H. Bouzerzour, "Analyse de la Stabilité des Performances de Rendement du blé dur (Triticum durum Desf.) sous Conditions Semi-Arides," Biotechnology, AgroNomy, Society and Environment, Vol. 14, No.1, 2010, pp. 177-186.

[22] Z. Berzsenyi, B. Gyorffy and D. Lap, "Effect of Crop Rotation and Fertilisation on Maize and Wheat Yields and Yield Stability in a Long-Term Experiment," European Journal of Agronomy, Vol. 13, No. 2-3, July 2000, pp. 225-244. doi:10.1016/S1161-0301(00)00076-9

[23] P. R. Hobbs, K. Sayre and R. Gupta, "The Role of Conservation Agriculture in Sustainable Agriculture," Philosophical Transactions of the Royal Society, B 2008, Vol. 363, No. 1491, February 2008. pp. 543-555.

[24] SAS Institute, "SAS User’s Guide: Statistics," 6th Edition, SAS Institute, Cary, 1995.

[25] R. C. Littell, G. A. Milliken, W. W. Stroup and W. W. Wolfinger, "SAS System for Mixed Models," SAS Institute, Cary, 1996.

[26] R. D. Wolfinger and M. Chang, "Comparing the SAS GLM and Mixed Procedures for Repeated Measures," Technical Report, SAS Institute Inc., Cary, 1998.

[27] P. Annicchiarico, “Genotype X Environment Interactions: Challenges and Opportunities for Plant Breeding and Cultivar Recommendations," FAO Plant Production and Protection Paper No. 174, FAO Publication, Rome, 2002.

[28] W. Yan and N. A. Tinker, "Biplot Analysis of MultiEnvironment Trial Data: Principles and Applications," Canadian Journal of Plant Sciences, Vol. 86, No. 3, July 2006, pp. 623-645. doi:10.4141/P05-169

[29] S. Lahlou, M. Ouadia, O. M. Issa, Y. Le Bissonnais and R. Mrabet, "Modification de la Porosité du Sol Sous les Techniques Culturales de Conservation en Zone Semiaride Marocaine,” Etude et Gestion des Sols, Vol. 12, No. 1, January 2005, pp. 69-76.

[30] K. Ibno-Namr and R. Mrabet, "Influence of Agricultural 
Management on Chemical Quality of a Clay Soil of Semiarid Morocco," Journal of African Earth Sciences, Vol. 39, No. 3-5, 2004, pp. 485-489.

doi:10.1016/j.jafrearsci.2004.07.016

[31] M. J. Jones, “Comparison of Conservation Tillage Systems in Barley-Based Cropping Systems in Northern Syria,” Experimental Agriculture, Vol. 36, No. 1, September 2000, pp. 15-26.

[32] C. J. Baker, R. Ritchie and K. E. Saxton, "The Nature of Risk in No-Tillage,” In: C. J. Baker et al., Eds., No-Tillage Seeding in Conservation Agriculture, 2nd Edition, FAO_CABI Publication, Rome, 2007, pp. 21-33.

[33] E. H. Bourarach, A. Bouzza and A. Nousfi, "Développement d'un Système d'Enterrage de Semoir Direct pour le Travail en Sol Sec," Hommes Terre \& Eaux, Vol. 28, No. 109, 1998, pp. 5-10.

[34] R. Mrabet, "Differential Response of Wheat to Tillage Management Systems in a Semiarid Area of Morocco," Field Crops Research, Vol. 66, No. 2, May 2000, pp. 165-174. doi:10.1016/S0378-4290(00)00074-5

[35] K. W. Finlay and G. N. Wilkinson, "The Analysis of Adaptation in a Plant-Breeding Programme,” Australian Journal of Agricultural Research, Vol. 14, No. 6, November-December 1963, pp. 742-754.

[36] C. J. Peterson, J. M. Moffat and J. R. Erickson, "Yield Stability of Hybrid vs. Pure Line Hard Winter Wheat in Regional Performance Trials," Crop Science, Vol. 37, No. 1, 1997, pp. 116-120. doi:10.2135/cropsci1997.0011183X003700010019x

[37] F. Shaxon and R. Barber, "Optimizing Soil Moisture for Plant Production: The Significance of Soil Porosity," FAO Soils Bulletin 79, Food and Agriculture Organization of the United Nations, Rome, 2003, p. 107.

[38] D. Moret, J. L. Arrúe, M. V. López and R. Gracia, "Winter Barley Performance under Different Cropping and Tillage Systems in Semiarid Aragon (NE Spain),” European Journal of Agronomy, Vol. 26, No. 3, April 2007, pp. 54-63. doi:10.1016/j.eja.2006.08.007

[39] J. Lampurlanès, P. Angas and C. Cantero-Martinez, "Tillage Effects on Water Storage during Fallow and on Barley Root Growth and Yield in Tow Contrasting Soils of the Semi-Arid Segarra Region in Spain,” Soil \& Tillage Research, Vol. 65, No. 2, May 2002, pp. 207-220. doi:10.1016/S0167-1987(01)00285-9

[40] K. E. Giller, E. Witter, M. Corbeels and P. Tittonell, "Conservation Agriculture and Smallholder Farming in Africa: The Heretics' View,” Field Crops Research, Vol. 114, No. 1, October 2009, pp. 23-34. doi:10.1016/j.fcr.2009.06.017

[41] P. C. Wall, "Tailoring Conservation Agriculture to the Needs of Small Farmers in Developing Countries,” Journal of Crop Improvement, Vol. 19, No. 1, March 2007, pp. 137-155. doi:10.1300/J411v19n01_07

[42] M. Pala, J. Ryan, H. Zhang, M. Singh and H. C. Harris, "Crop Water-Use Efficiency of Wheat-Based Rotation Systems in a Mediterranean Environment,” Agricultural
Water Management, Vol. 93, No. 3, November 2007, pp. 136-144. doi:10.1016/j.agwat.2007.07.001

[43] Y. Ding, K. Schoengold and T. Tadesse, "The Impact of Weather Extremes on Agricultural Production Methods: Does Drought Increase Adoption of Conservation Tillage Practices?” Journal of Agricultural and Resource Economics, Vol. 34, No. 3, December 2009, pp. 395-411.

[44] K. J. McAneney and J. L. Arrúe, “A Wheat-Fallow Rotation in Northeastern Spain: Water Balance-Yield Considerations,” Agronomie, Vol. 13, No. 6, March 1993, pp. 481-490. doi:10.1051/agro:19930604

[45] H. J. Farahani, G. A. Peterson and D. G. Westfall, "Dryland Cropping Intensification: A Fundamental Solution to Efficient Use of Precipitation,” Advances in Agronomy, Vol. 64, 1998, pp. 197-223. doi:10.1016/S0065-2113(08)60505-2

[46] P. Bescansa, M. J. Imaz, I. Virto, A. Enrique and W. B. Hoogmoed, "Soil Water Retention as Affected by Tillage and Residue Management in Semiarid Spain,” Soil \& Tillage Research, Vol. 87, No. 1, May 2006, pp. 19-27. doi:10.1016/j.still.2005.02.028

[47] O. Erenstein, "Crop Residue Mulching in Tropical and Semi-Tropical Countries: An Evaluation of Residue Availability and Other Technological Implications,” Soil \& Tillage Research, Vol. 67, No. 2, September 2002, pp. 115-133. doi:10.1016/S0167-1987(02)00062-4

[48] R. Lal, "Constraints to Adopting No-Till Farming in Developing Countries,” Soil \& Tillage Research, Vol. 94, No. 1, April 2007, pp. 1-3. doi:10.1016/j.still.2007.02.002

[49] A. Ramdani, R. Mrabet and H. G. Macpherson, "Performance of Moroccan Wheat Cultivars under Tillage Systems and Water Regimes," Journal of Agricultural Science and Technology, Vol. 4, No. 5, October 2010, pp. 106-111.

[50] R. Mrabet, "Wheat Yield and Water Use Efficiency Under Contrasting Residue and Tillage Management Systems in a Semiarid Area of Morocco," Experimental Agriculture, Vol. 38, No. 2, April 2002, pp. 237-248. doi:10.1017/S0014479702000285

[51] G. Bellocchi, M. Rivington, M. Donatelli and K. Matthews, "Validation of Biophysical Models: Issues and Methodologies. A Review," Agronomy for Sustainable Development, Vol. 30, No. 1, 2010, pp. 109-130. doi:10.1051/agro/2009001

[52] M. J. Imaz, I. Virto, P. Bescansa, A. Enrique, O. Fernandez-Ugalde and D. L. Karlen, "Soil Quality Indicator Response to Tillage and Residue Management on Semi-Arid Mediterranean Cropland,” Soil \& Tillage Research, Vol. 107, No. 1, March 2010, pp. 17-25. doi:10.1016/j.still.2010.02.003

[53] R. Lal, "Carbon Sequestration in Dryland Ecosystems of West Asia and North Africa," Land Degradation \& Development, Vol. 13, No. 1, January/February 2002, pp. 45-59. doi:10.1002/ldr.477

[54] P. Debaeke and A. Aboudrare, “Adaptation of Crop 
Management to Water-Limited Environments,” European Journal of Agronomy, Vol. 21, No. 4, December 2004, pp. 433-446. doi:10.1016/j.eja.2004.07.006

[55] H. Gomez-Macpherson, H. Boulal, R. Mrabet and E. Gonzalez, "Rational and Application of Conservation Agriculture for Irrigated Production in Southern Europe and North Africa," Proceedings of 4th World Congress on Conservation Agriculture: Innovations for Improving Efficiency, Equity and Environment, Delhi, 4-7 February, 2009, pp. 129-135.

http://www.fao.org/ag/ca/doc/wwcca-leadpapers.pdf. 